\title{
Pseudo-endemism and cryptic diversity in Lepidoptera - case studies from the Alps and the Abruzzi
}

\section{Peter Huemer}

Keywords: Alpine endemism, pseudo-endemism, cryptic diversity, barcoding, Alps, Abruzzi, butterflies, moths, Lepidoptera

\section{Abstract}

The Alps are a hotspot of endemism for Lepidoptera with $230+$ species occurring only in this area. In discussing endemism there is, however, a high risk of relying on biased spatial and taxonomic data. Pseudo-endemism may be much more widespread than expected as proved by a week-long excursion to Gran Sasso National Park and Monte Terminillo (Central ltaly). Results of this research are five species hitherto only known from the Alps: Aspilapteryx spectabilis Huemer, 1994, Agonopteryx alpigena (Frey, 1870), Depressaria incognitella Heinemann, 1990, Pammene laserpitiana Huemer \& Erlebach, 1999 and Epermenia theimeri Gaedike, 2001; and several additional taxa not yet known from central Italy. Not only is our knowledge of distribution incomplete, alpha-taxonomy of numerous Lepidoptera has been insufficiently explored to date. A transnational barcoding project of all Alpine Lepidoptera within the framework of the International Barcode of Life project (iBOL) is providing strong evidence of much higher levels of cryptic diversity than hitherto known. Examples of probably as yet undescribed Alpine taxa, based on combined molecular and morphological datasets, are demonstrated for the genera Callisto, Eulamprotes and Caryocolum.

\section{Introduction}

Butterflies and moths are groups of animals beloved by a great number of people. The beauty of many species and the fascinating metamorphosis may be responsible for a long history of exploration of Lepidoptera in Europe dating back to the Linnean period more than 250 years ago. More than other orders of invertebrates, butterflies and moths have attracted the life-long interest of a large number of amateurs and professional entomologists. As a result of these efforts, species diversity on the European continent is nowadays considered sufficiently well known, at least outside the scientific community. More than 9000 described species out of 180000 globally have been recorded so far (Karsholt \& Razowski 1996). The Alps, as one of the mega-diverse regions, host an estimated 5500 species. Major parts of the fauna are more or less widely distributed in Europe and/ or Palaearctic Asia or even in the Holarctic, whereas endemic taxa restricted to the Alpine Arc or parts of it are less diverse. However, compared with other European ecosystems, the Alps are clearly a hotspot of Lepidoptera in terms of endemism (Huemer 1998). Specific biology and habitat requirements as well as historical glaciation processes strongly influenced the survival of species in unglaciated parts of the Alps (massifs de refuge and nunataks) or in adjacent refugia and subsequent re-colonization (Holdhaus 1954). Recent distribution patterns of Alpine endemics reflect these influences and the large majority of species is restricted to a fairly small area (Huemer 1998, 2009a).
Profile

Mountain range

Alps \& Abruzzi

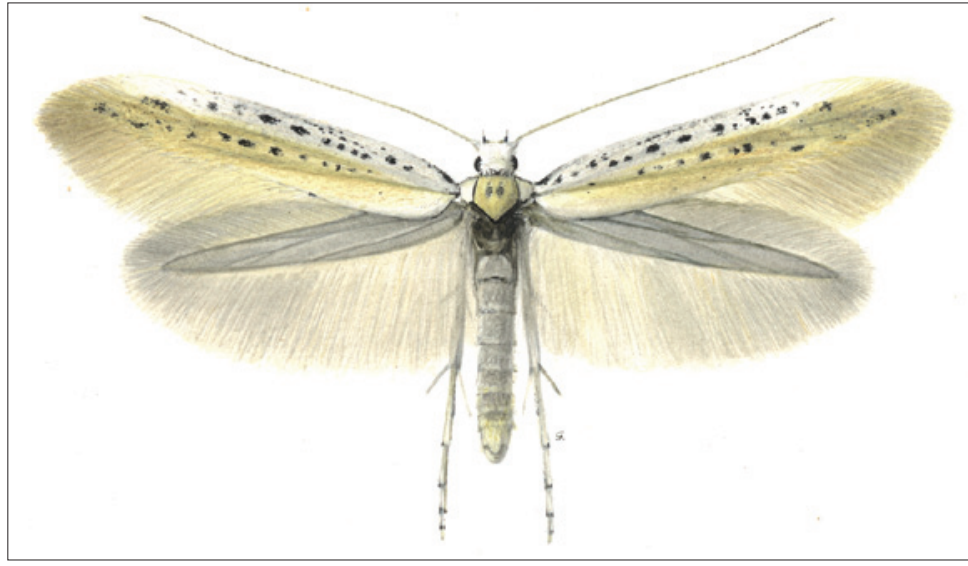

Figure 1 - Aspilapteryx spectabilis, hitherto only known from Hohe Tauern National Park (NP), water colour by F. Gregor. (C) Tiroler Landesmuseum (TLM)

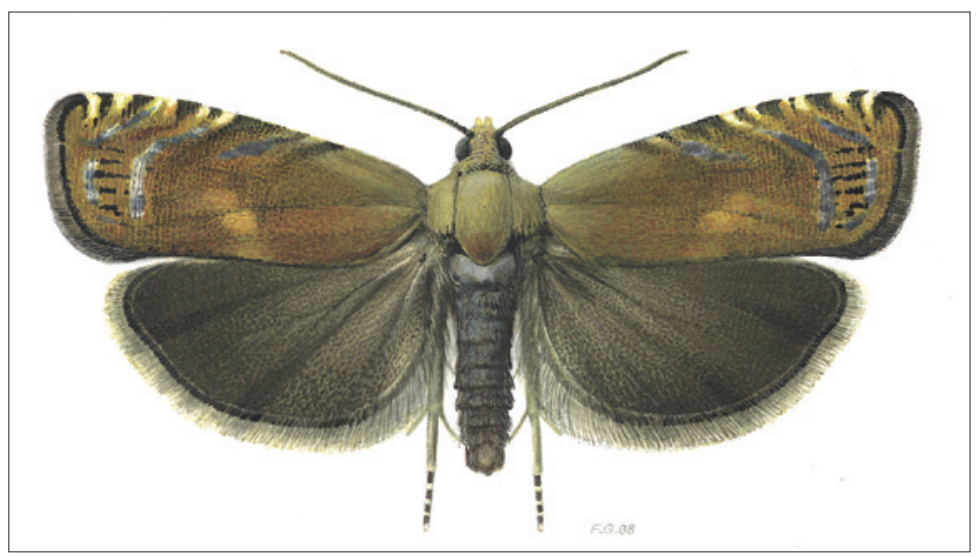

Figure 2 - Pammene laserpitiana, initially described from the southern Alps (Monte Baldo, Fennberg), water colour by F. Gregor. (C) TLM 


\section{Results}

\section{Pseudo-endemism}

Endemics of the Alps are thought to occur only in this mountain area, but such endemism is based on current knowledge of taxonomy and distribution. Obviously these data may be fragmentary and do not necessarily reflect the actual distribution of the species. Taxa where inadequate or uneven surveys have led to a false interpretation of endemism are in fact pseudo-endemics (Cowling 2001). Results from our field research in central Italy support the assumption of widespread pseudo-endemism in Lepidoptera, with records of no fewer than five allegedly Alpine endemics occurring in the Abruzzi:

Aspilapteryx spectabilis Huemer, 1994 (Gracillariidae) (Figures $1 \& 5$ ): This species was hitherto only known from the Virgental in East Tyrol (Hohe Tauern NP) (Huemer 1994; 2009). It seems to be restricted to south-facing slopes on limestone at elevations of about 2200 to $2660 \mathrm{~m}$ in this area. However, there are large gaps in our knowledge of its biology and habitat preferences, although it is suspected that the larva may be a leaf-miner on an Alpine species of Plantago. New record: Italy, L'Aquila, Gran Sasso NP, Campo Imperatore, E Observatorio, $2010 \mathrm{~m}, 1^{\circ} 34,4^{\prime} \mathrm{E}$, $42^{\circ} 26,9^{\prime} \mathrm{N}, 13.7 .2010$, leg. Huemer.

Agonopteryx alpigena (Frey, 1870) (Depressariidae) (Figure 6): Already described in 1870 , this species has been recorded from the entire Alpine Arc, ranging from the French Alps to eastern Austria and from Bavaria to northern Italy and Slovenia. An alleged record from Hungary (Hannemann 1995) remains unconfirmed and is highly unlikely. The larva is restricted to Laserpitium siler and feeds on spun leaves of the host plant. New record: Italy, L'Aquila, Gran Sasso NP, Campo Imperatore, ex Miniera di Lignite, $1750 \mathrm{~m}$, $13^{\circ} 42^{\prime} 48^{\prime \prime} \mathrm{E}, 42^{\circ} 25^{\prime} 36^{\prime}$ N N 14.7.2010.

Depressaria incognitella Hannemann, 1990 (Depressariidae): This species was hitherto only recorded from few specimens collected in the French, Italian and Swiss Alps (Hannemann 1990; Huismann \& Sauter 2001; SwissLepTeam 2010). Nothing has been published about its biology so far. Judging from related species, it may be suspected that the larva feeds on Apiaceae. New record: Italy, L'Aquila, Gran Sasso NP, Campo Imperatore, E Observatorio, $2010 \mathrm{~m}$, $13^{\circ} 34^{\prime} 24^{\prime \prime}$ E, 42 26'54” N, 13.7.2010, leg. Huemer. Pammene laserpitiana Huemer \& Erlebach, 1999 (Tortricidae) (Figures 2 \& 5): Huemer \& Erlebach (1999) described this tortricoid moth from a small corridor of the southern Alps, ranging from Monte Baldo (prov. Verona) to Fennberg (prov. Bolzano). Recently it was also recorded from Slovenia. The type series was bred from seed capsules of $L a$ serpitium siler. New records: Italy, L'Aquila, Gran Sasso NP, Campo Imperatore, ex Miniera di Lignite, $1750 \mathrm{~m}, 13^{\circ} 42^{\prime} 48^{\prime \prime} \mathrm{E}, 42^{\circ} 25^{\prime} 36^{\prime}$ N, 14.7 .2010 ; Italy, Rieti, Monte Terminillo N, 1730-1780 m,

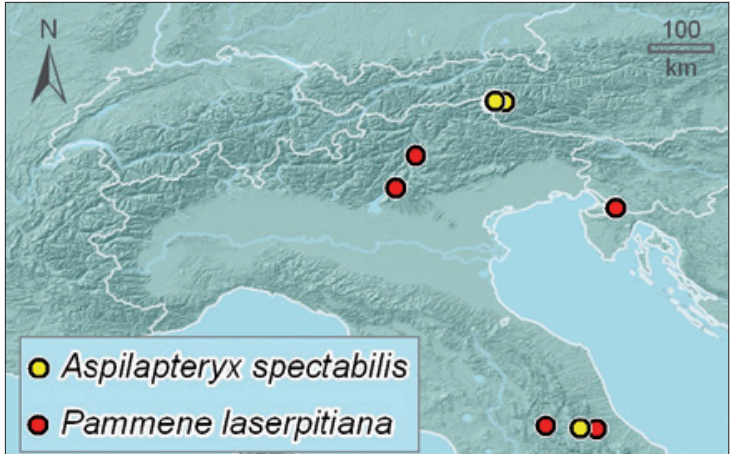

Figure 5 -Distribution pattern of Aspilapteryx spectabilis and Pammene laserpitiana. C TLM

$13^{\circ} 0^{\prime} 0^{\prime} \mathrm{E}, \quad 42^{\circ} 29^{\prime} 0^{\prime} \mathrm{N}$, 16.7.2010, leg. Huemer. Epermenia theimeri Gaedike, 2001 (Epermeniidae): Gaedike (2001) described this species based on a male and female specimen from Monte Baldo in northern Italy and without any information about the biology. Nothing has been added since the original publication. The new records from Monte Terminillo (Figure 7) in central Italy indicate that E. theimeri may be associated with Laserpitium siler, which is a common plant at all collecting sites. New record: Italy, Rieti, Monte Terminillo N, 1730-1780 m, 130'0” E, 42 29' 0" N, 16.7.2010, leg. Huemer.

Apart from these findings, several additional species with limited distribution in European mountain systems are new records to the Gran Sasso NP and central Italy e.g. Kessleria saxifragae (Stainton, 1868) (Yponomeutidae), Aethes ardezana (Müller-Rutz, 1922) and Pelatea klugiana (Freyer, 1836) (Tortricidae). And last but not least, a number of undescribed species point to considerable research gaps, even in national parks.

\section{Cryptic diversity}

Cryptic species complexes are reproductively isolated but morphologically very similar and sometimes virtually identical taxa. Such hidden diversity can only be resolved on a physiological or genetic scale, which

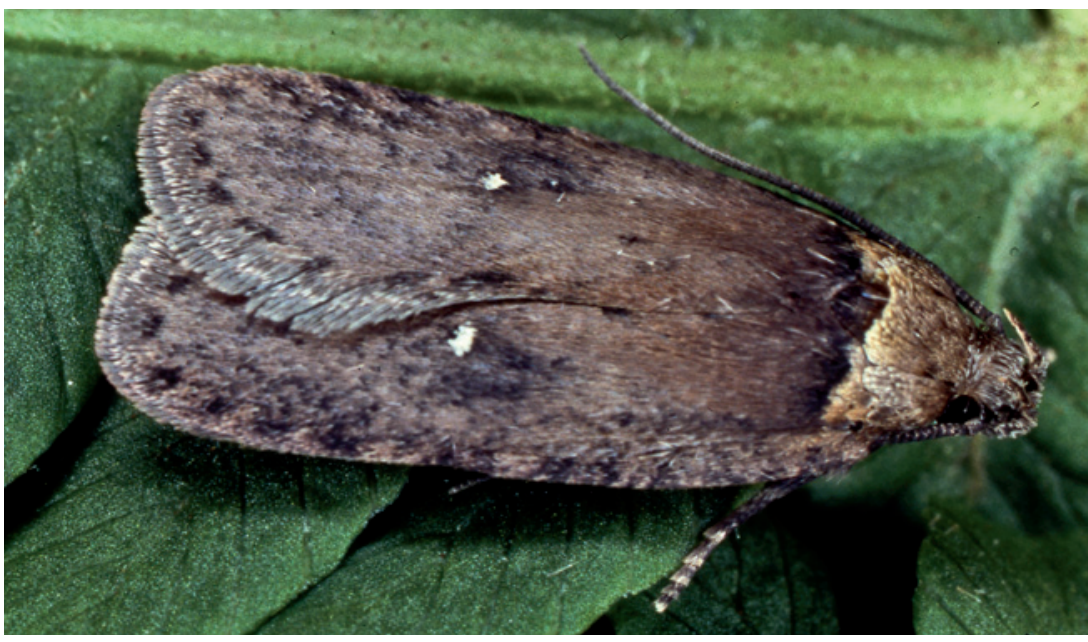

Figure 6 - Agonopterix alpigena, one of three pseudoendemics with trophic linkage to Laserpitium siler. (C) TLM \& S. Erlebach 
phy and confined to the south-western, central, southern and south-eastern Alps with an allopatric pattern of distribution. The fifth lineage is restricted to the south-western Alps and specimens from this area occur syntopically with the lineage first mentioned (Figures $10 \& 11)$. In this lineage we face a situation where speciation has gone far and gene flow is already interrupted. Examination of voucher material resulted in distinct morphological characters of the fifth lineage compared with other samples (Figures 12 \& 13). However, the taxonomic status of four genetic lineages is insufficiently resolved due to a lack of female specimens which offer the most reliable morphological characters.

Intra- or interspecific molecular divergence Caryocolum peregrinella-group: Caryocolum peregrinella (Herrich-Schäffer, 1854) as currently defined (Huemer \& Karsholt 2010a) splits into three genetic lineages correlated with the south-western and southeastern Alps and the Balkans (Dinaric Mountains to Olymp) (Figure 14). Sequence variation at COI between clusters is high, with deep splits of $4.46 \%$ to $5.34 \%$, whereas it is low within the lineages (Figure 15). However, preliminary analysis of morphological characters is at odds with barcode differentiation and does not support specific status. Despite this shortcoming, Caryocolum peregrinella could well represent an overlooked case of cryptic diversity. Even though this may be scientifically proven in future, one problem has to be considered: the type locality of the species is unknown, the abdomen of the lectotype is missing and the age of more than 150 years (Huemer 1988) will be a major hindrance for recovering DNA.

\section{Discussion}

Species diversity is increasingly threatened as documented for instance in the IUCN Red List of Threatened Species and multiple national or regional Red Data Books. Intensified agriculture and forestry, pollution of soil, water and air, excessive infrastructure etc. lead to a dramatic loss of diversity in terms of species and habitats. Protection measures will be of particular importance for endemics with limited distribution, which define the uniqueness of many Alpine areas and should be regarded as a specific treasure (Komposch 2010; Rabitsch \& Essl 2009). But what do we really know about endemics in the Alps? Do we rely on biased spatial data? And is alpha-taxonomy of species sufficiently explored? Lepidoptera may be a case in point. The detection of a considerable number of allegedly Alpine endemic species outside the Alps, in the Abruzzi, shows up the huge gaps in knowledge about actual distribution. The discovery of such species in central Italy is not per se unexpected, but the quality and quantity of taxa is surprising. Extensive and specific search in related European mountain systems will be necessary to prove the endemic status of every single

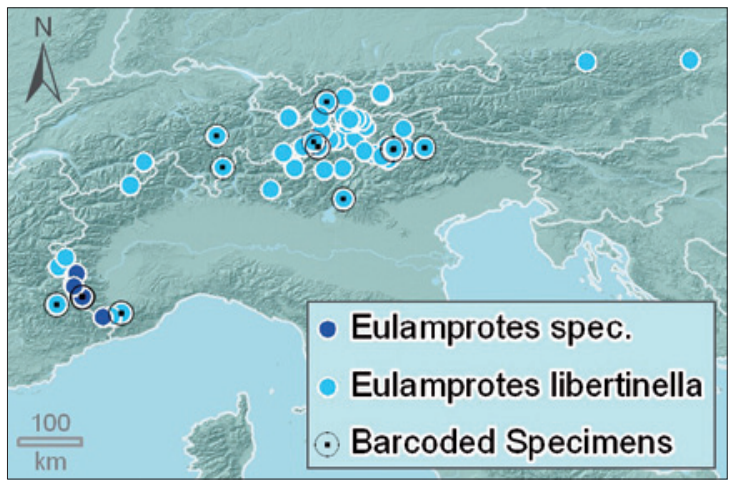

Figure 10 - Distribution pattern of Eulamprotes libertinella-complex. (C) TLM

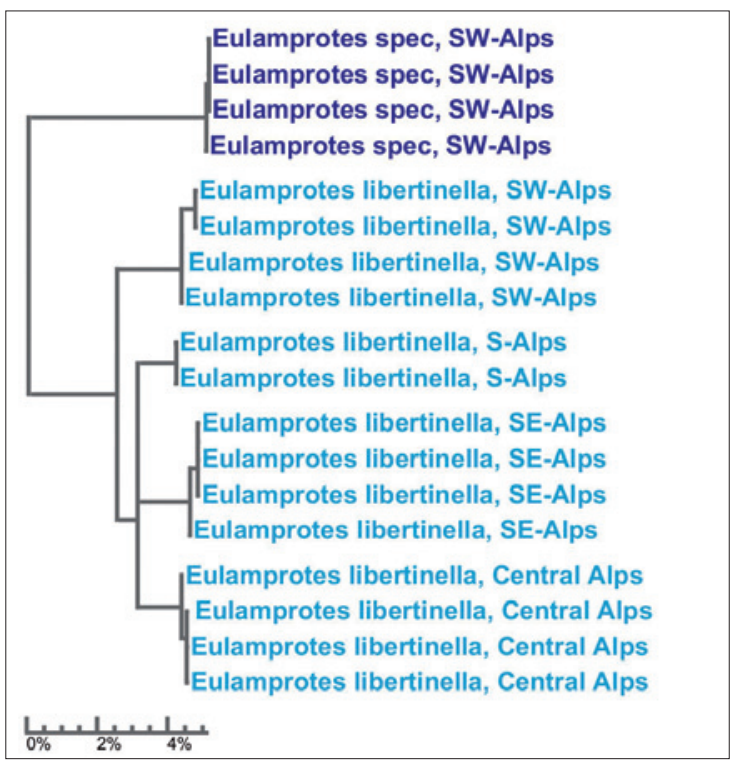

Figure 11 - Genetic distance from the COI barcode fragment of the Eulamprotes libertinella-complex. (C) TLM
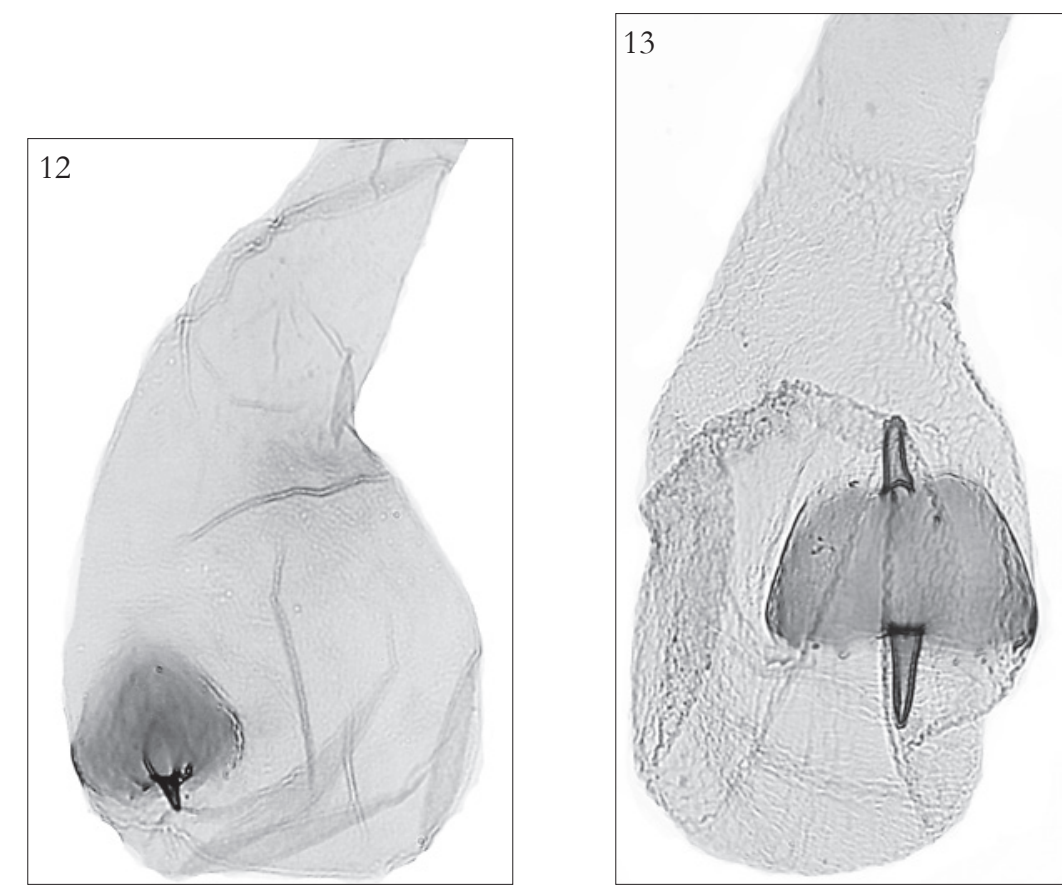

Figure $12 \& 13$ - Diagnostic and morphological characters of female genitalia in the Eulamprotes libertinella-complex. (C) TLM 


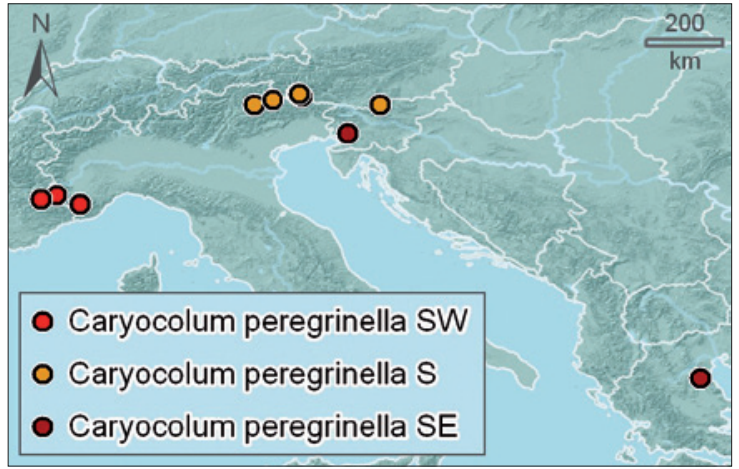

Figure 14 - Distribution pattern of Caryocolum peregrinella in the Alps. (C) TLM

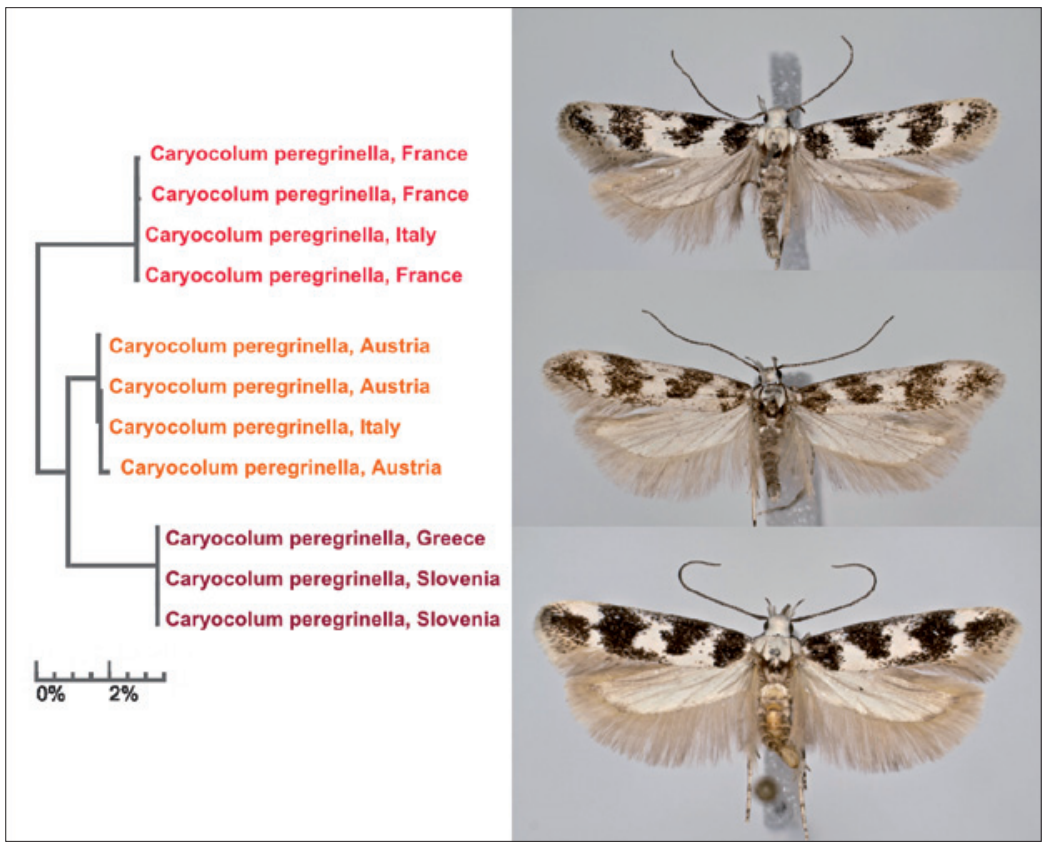

Figure 15 - Genetic distance from the COI barcode fragment and habitus characters of Caryocolum peregrinella. (C) TLM

taxon. Particularly the Balkans, the mountains of central Italy and the Pyrenees and Cantabrian mountains are insufficiently explored, despite their close affinities to the Alps. It is very likely that further endemics will be lost with increasing field research outside the Alps. Conversely, molecular datasets may throw up a considerable number of taxa in the Alps unrecognized to date. Different genetic lineages, frequently reflected in morphology, are widespread in Alpine organisms. The most common feature in plants is a differentiation into four genetic units confined to the south-western, western central, eastern central and eastern Alps (Schönswetter et al. 2005), whereas in animals, genetic units may be similar or often reduced to a western and an eastern lineage (Schmitt 2009). Genetic and morphological differences may be pronounced, as observed for instance in the Alpine endemic butterfly Erebia melampus (Fuessly, 1775), see Figure 16, where they are likely to be of interspecific value (Haubrich \& Schmitt 2007). However, the number of Lepidoptera species analysed so far is limited and molecular research is usually restricted to butterflies. Our bar- coding project is a comprehensive attempt to test the usefulness of molecular data for taxonomy of Alpine Lepidoptera. First results are promising but the coverage of species with successfully sequenced barcodes is still limited. Despite of the long tradition of Lepidopterology in Europe and large collections in museums, the lack of suitable material is a major hindrance for a rapid progress in barcoding. In many cases, age and conservation status of specimens have turned out to be inadequate for successful sequencing. Furthermore, even major collections are seriously incomplete and particularly lack rare species such as many endemic micromoths. Despite these shortcomings, initial amounts of molecular data point to a high amount of hidden species richness in the Alps. Such cryptic diversity seems to be higher than average in flightless species and hitherto unknown examples are found in several genera, e.g. Kessleria, Symmoca, Eulamprotes and Sattleria. Partial reduction of wings (brachypterous, stenopterous and micropterous species) or complete reduction (apterous species) is a rare exception in Alpine Lepidoptera. It is only observed in less than $1 \%$ of the world fauna, though present in 25 families and adopted as a successful family strategy in the Psychidae (Sattler 1991). However, flightlessness is remarkably widespread in Alpine endemics, with about one fifth of the species inventory (Huemer 1998). In the Alpine environment it is interpreted as adaptation to climatic risks such as strong wind and low temperatures. Important consequences of flightlessness are reduced dispersal capacities, which probably have led to increased isolation and disturbance or interruption of gene flow. Further examples of cryptic diversity are to be expected in such comparatively immobile species. Moreover, barcodes - even though still fragmentary give some evidence to several genetic lineages in fully winged species. Particularly noticeable diversification can be observed in the southern Alps (e.g. Dolomites), south-western Alps and north-eastern Alps. Several of these genetic lineages may be attributed to species complexes, but morphological data are still lacking for many of them. Integrative taxonomy with involving multiple disciplines (Schlick-Steiner et al. 2010) may be of crucial value for delimiting such cryptic diversity in future.

\section{Acknowledgments}

The author would like to thank his companion Toni Mayr for help with fieldwork in the Abruzzi. Marcello Maranella and the authorities of the Gran Sasso NP kindly issued the necessary collecting permits. Samples from the south-western Alps were partially collected within the framework of ATBI (All Taxa Biodiversity Inventory) and I would like to thank Marie-France Leccia and Marta de Biaggi and the whole staff of Mercantour NP and Alpi Marittime Nature Park. Research in Hohe Tauern NP was kindly supported by the board of directors of this park, Peter Rupitsch, 
Hermann Stotter and Wolfgang Urban, and scientific staff Katharina Aichhorn, Kristina Bauch and Martin Kurzthaler. Molecular data are based on sequencing work executed by the team of the Biodiversity Institute of Ontario, University of Guelph and I am deeply indebted to Paul Hebert and his team. Marko Mutanen kindly offered various barcode data. Siegfried Erlebach, Stefan Heim and Marlies Mayr are gratefully acknowledged for photographic work and Hannes Kühtreiber for preparing maps and diagrams. Several unnamed entomologists have added to this work with material and data input. Two anonymous reviewers improved the work with constructive comments. Last but not least, I am most grateful to the editorial team of eco.mont, Brigitte Scott and Valerie Braun, for support in the preparation of the manuscript.

\section{References}

Cowling, R.M. 2001. Endemism. Encyclopedia of Biodiversity 2: 497-507.

Elsner, G., P. Huemer \& Z. Tokár 1999. Die Palpenmotten (Lepidoptera, Gelechiidae) Mitteleuropas. Bestimmung - Verbreitung - Flugstandort - Lebensweise der Raupen. Bratislava.

Gaedike, R. 2001. Eine neue Epermenia Hübner, [1825], vom Monte Baldo (Lepidoptera: Epermeniidae). Entomologische Zeitschrift Stuttgart 111: 230-231.

Hannemann, H. J. 1990. Neue Depressarien (Lep., Oecophoridae). Deutsche entomologische Zeitschrift, N. F. 37: 137-145.

Hannemann, H.J. 1995. Kleinschmetterlinge oder Microlepidoptera. IV. Flachleibmotten (Depressariidae). In: Dahl, F. (Begr.) \& H. Schumann (Hrsg.), Die Tierwelt Deutschlands und der angrenzenden Meeresteile nach ibren Merkmalen und nach ibrer Lebensweise. 69. Teil. Jena.

Haubrich, K. \& T. Schmitt 2007. Cryptic differentiation in alpine-endemic, high-altitude butterflies reveals down-slope glacial refugia. Molecular Ecology 16: 3643-3658.

Hebert, P.D.N., A. Cywinska, S.L. Ball \& J.R. deWaard 2003. Biological identifications through DNA barcodes. Proceedings of the Royal Society of London B 270: 313-321.

Holdhaus, K. 1954. Die Spuren der Eiszeit in der Tierwelt Europas. Abhandlungen der zoologisch-botanischen Gesellschaft in Wien 18: 1-493.

Huemer, P. 1988. A taxonomic revision of Caryocolum (Lepidoptera: Gelechiidae). Bulletin of the British Museum (Natural History), Entomology series 57: 439-571.

Huemer, P. 1994. Aspilapteryx spectabilis sp.n., eine neue Schmetterlingsart aus dem Gebiet des Nationalparks Hohe Tauern (Osttirol, Österreich) (Lepidoptera: Gracillariidae). Zeitschrift der Arbeitsgemeinschaft österreichischer Entomologen 46: 1-8.

Huemer, P. 1998. Endemische Schmetterlinge der Alpen - ein Überblick (Lepidoptera). Stapfia 55: 229_ 256.

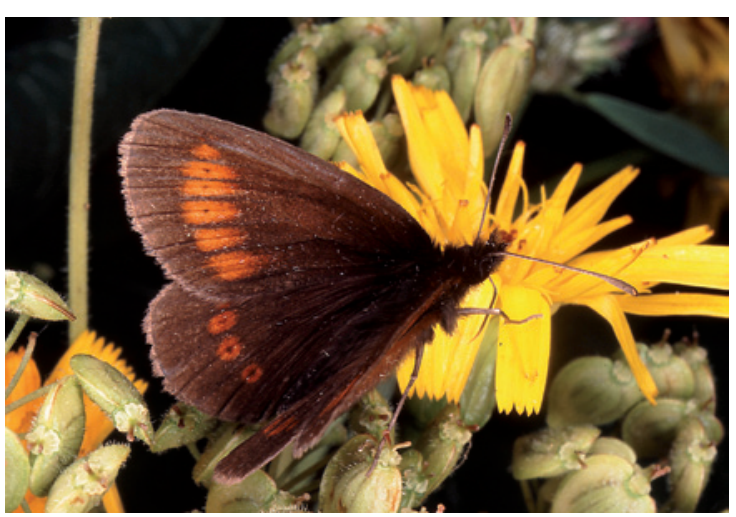

Figure 16 - Erebia melampus, a well studied example of allegedly cryptic diversity in butterflies. (C) TLM \& S. Erlebach

Huemer, P. 2009a. Lepidoptera (Schmetterlinge). In: Rabitsch, W. \& F. Essl (Red.), Endemiten - Kostbarkeiten in Österreichs Pflanzen- und Tierwelt. 810-844. Klagenfurt \& Wien.

Huemer, P. 2009b. Dichrorampha tarmanni sp. n. - ein Verwechslungsfall bei alpinen Schmetterlingen (Lepidoptera, Tortricidae). Wissenschaftliches Jahrbuch der Tiroler Landesmuseen 2: 110-119.

Huemer, P. 2010. Argyresthia friulii sp. n., a new species from the Julian Prealps, Northern Italy (Lepidoptera, Yponomeutidae). Gortania, Atti del Museo Friulano di Storia naturale 31: 137-142.

Huemer, P. \& S. Erlebach 1999. Pammene laserpitiana sp.n., ein neuer Endemit der Südalpen (Lepidoptera: Tortricidae). Quadrifina 2: 231-240.

Huemer, P. \& A. Hausmann 2009. A new expanded revision of the European high mountain Sciadia tenebraria species group (Lepidoptera: Geometridae). Zootaxa 2117: 1-30.

Huemer, P. \& O. Karsholt 2010a. Gelechiidae II (Gelechiinae: Gnorimoschemini). In: Huemer, P., O. Karsholt \& M. Nuss (eds.), Microlepidoptera of Europe 6. Stenstrup.

Huemer, P. \& O. Karsholt 2010b. A new endemic species of Monochroa from the south-western Alps (Lepidoptera: Gelechiidae). Zeitschrift der Arbeitsgemeinschaft österreichischer Entomologen 62: 81-86.

Huismann, K.J. \& W. Sauter 2001. Redescription of the female and distribution of Depressaria incognitella Hannemann, 1990 (Depressariidae). Nota lepidopterologica 24 (4): 35-41.

Ivanova, N.V., J.R. deWaard \& P.D.N. Hebert 2006. An inexpensive, automation-friendly protocol for recovering high-quality DNA. Molecular Ecology Notes 6: 998-1002.

Karsholt, O. \& J. Razowski 1996. The Lepidoptera of Europe. A Distributional Checklist. Stenstrup.

Komposch, Ch. 2010. Alpine treasures - Austrian endemic arachnids in Gesäuse National Park. eco.mont 2 (2): 21-28.

Mayr, E. 1970. Populations, species, and evolution: an abridgment of Animal species and evolution. Cambridge, Massachusetts. 
Newbold, T. 2010. Applications and limitations of museum data for conservation and ecology, with particular attention to species distribution models. Progress in Physcial Geography 34 (1): 3-22.

Rabitsch, W. \& F. Essl (Red.) 2009. Endemiten - Kostbarkeiten in Österreichs Pflanzen- und Tierwelt. Klagenfurt \& Wien.

Ratnasingham, S. \& P.D.N. Hebert 2007. BOLD: The Barcode of Life Data System (http://www.barcodinglife.org). Molecular Ecology Notes 7: 355-364.

Sattler, K. 1991. A review of wing reduction in Lepidoptera. Bulletin of the British Museum (Natural History), Entomology series 60: 243-288.

Schlick-Steiner, B.C., F.M. Steiner, B. Seifert, C. Stauffer, E. Christian \& R.H. Crozier 2010. Integrative Taxonomy: A Multisource Approach to Exploring Biodiversity. Annual Review of Entomology 55: 421-438.

Schmitt, T. 2009. Biogeographical and evolutionary importance of the European high mountain systems. Frontiers in Zoology 6: 9-18.

Schönswetter, P., I. Stehlik, R. Holderegger \& A. Tribsch 2005. Molecular evidence for glacial refugia of mountain plants in the European Alps. Molecular Ecology 14: 3547-3555.

Scopoli, J.A. 1763. Entomologia Carniolica. Wien.

SwissLepTeam 2010. Die Schmetterlinge (Lepidoptera) der Schweiz: Eine kommentierte systematischfaunistische Liste. Fauna Helvetica 25: 1-349.

Varenne, T. \& J. Nel 2010. Eucosma catoptrana (Rebel, 1903), espèce confirmée pour la France, nouvelle pour la Corse, et description de Monochroa albagonella n. sp. (Lep. Tortricidae et Gelechiidae). Oreina 9: 18-19.

Whitebread, S. 2007. Sphaleroptera alpicolana (Frölich 1830) (Lepidoptera, Tortricidae, Cnephasiini): a species complex. Veröffentlichungen des Tiroler Landesmuseums Ferdinandeum 86: 177-204.

Zeller, P.C. 1872. Bemerkungen über einige Graubündner Lepidoptern. Stettiner entomologische Zeitung 33: 97-120.

\section{Author}

\section{Peter Huemer}

is a biologist working at the Tiroler Landesmuseum in Innsbruck with a scientific focus on Lepidoptera. His research covers taxonomy, ecology and biogeography of Alpine Lepidoptera and he described about 80 new species from this area. Conservational aspects are reflected by publications of several Red Lists and intensive research into light pollution.

Tiroler Landesmuseen Betriebsgesellschaft m.b.H., Naturwissenschaftliche Sammlungen, Feldstraße 11a, 6020 Innsbruck, Austria

p.huemer@tiroler-landesmuseen.at 